\title{
The Two Durkheims: Founders AND Classics in CANadian Introductory Sociology TeXtBooks
}

\author{
Peter Mallory \\ PATRICIA CORMACK
}

\begin{abstract}
For contemporary Durkheim scholars, the presentation of Durkheimian sociology in introductory textbooks is notoriously flawed. In this article, we examine the presentation of Durkheim's work in popular English-language Canadian sociology textbooks. We show that textbooks present two distinct "Durkheims." First, they characterize him as a founder of the discipline and the sociological project of challenging common-sense explanations of social life. Second, Durkheim appears as the father of structural functionalism who advocates a conservative, integrating vision of society. We argue that to understand why these two versions of Durkheim persist in sociology textbooks, we must appreciate the symbolic place of classical authors in the discipline. The two "textbook Durkheims" endure because they operate as symbols for both the coherence and divisions of the discipline. We suggest that integrating contemporary Durkheimian scholarship into textbooks would require revising conventional textbook approaches of sorting classical authors as founders of contending sociological perspectives.
\end{abstract}

Keywords: Durkheim; Sociological Theory; Textbooks; Sociological Pedagogy; Introductory Sociology; Collective Representations.

Résumé. Pour les spécialistes contemporains de l'oeuvre de Durkheim, la présentation de la sociologie durkheimienne dans les manuels d'introduction à la sociologie laisse beaucoup à désirer. Cet article jette un regard critique sur les manuels canadiens de langue anglaise. Nous constatons que ceux-ci dressent un portrait de Durkheim en deux volets: d'une part, comme fondateur de la discipline et de la démarche qui consiste à remettre en cause les explications de la vie sociale relevant du sens commun; et d'autre part, comme le héraut du structurofonctionnalisme, d'une vision conservatrice et intégratrice de la société. Pour comprendre la présence de cette dualité dans les manuels de sociologie, il faut comprendre la place symbolique qu'occupent les auteurs classiques dans la discipline. Les «deux Durkheims» perdurent parce qu'ils fonctionnent comme 
des repères symboliques à la fois de la cohérence de la discipline et de ses divisions. Pour mieux comprendre la recherche durkheimienne contemporaine, les manuels devraient remettre en question les approches conventionnelles qui trient les auteurs classiques comme fondateurs de perspectives sociologiques concurrentes.

Mots clés: Durkheim; théorie sociologique; Manuels; Pédagogie sociologique; Introduction à la sociolgie; Représentations collectives.

\section{INTRODUCTION}

A chance encounter in a university hallway was the inspiration for this paper. We met one afternoon on our way to and from our classes, one a second-year class on Émile Durkheim. As Durkheim scholars, we discussed how odd our own interest seems to our students who often consider him the dullest of the standard classical "Big Three." Certainly his imperative to "treat social facts as things" (Durkheim 2013: 7, 29) is not nearly as provocative as "workers of the world unite." Nonetheless, with concepts like solidarity, collective representations, collective effervescence, and the sacred and profane, his work should hold its own fascination, at least for those inclined to be fascinated by intellectual things. We suspected that if our students find Durkheim dull, they may not be reading him carefully_ - or more likely, not reading him at all and reading textbooks instead.

For Durkheim scholars, the presentation of his work in North American introductory textbooks is notoriously flawed. As Ramp writes, "Perhaps no other classical theorist except Marx has a popular reputation that labours under so much baggage, but for the casual reader, especially of introductory texts, much of that baggage is unseen - or, rather, it appears simply to be what Durkheim is" (2008: 147). Durkheim's baggage - having been pigeonholed as the founder of functionalism and a conservative defender of order-is a holdover from his association with Talcott Parsons. While Durkheim's work certainly influenced twentieth-century functionalism, it has been several decades since the functionalist Durkheim has been influential in advanced scholarship (Smith and Alexander 2005). Indeed, scholars have been developing rich new interpretations of Durkheim and the Durkheimian school. Thus, while the functionalist Durkheim has all but vanished from advanced scholarship, we can now point instead to a radical Durkheim (Gane 1992; Pearce 2001), a cultural Durkheim (Smith and Alexander 2005), a practice-based, ethnomethodological 
Durkheim (Garfinkel 2002; Rawls 2004), and an interactionist Durkheim (Collins 2004), to name only a few of the important reinterpretations of his work. Many of these readings of Durkheim have been driven by a new attention to his last and most developed work, The Elementary Forms of Religious Life (hereafter, Elementary Forms) (Datta and Milbrandt 2014).

The disjuncture between the richness of the new Durkheim scholarship and his representation in textbooks forms the starting point for our paper. Our aim is to examine the place of Durkheim in introductory textbooks as a way to raise broader questions about textbooks as collective representations and, more specifically, as representations through which sociology's foundational myths are narrated for the potential newcomer to the discipline. Certainly, sociology's interest in its own textbooks is not new, and one of the most heavily debated issues in the scholarship on textbooks is the relation of textbook sociology to advanced scholarship (Baker 1988; Keith and Ender 2004; Platt 2008; Schweingruber 2005; Wright 1995). Scholars have criticized textbooks for the use of outdated terminology (Best and Schweingruber 2003) and for the treatment of specific topics in ways that do not reflect the current field, for example, religion (Carroll 2017; Roberts 2017), environmental issues (Lewis and Humphrey 2005), crowds and social movements (Schweingruber and Wohlstein 2005), race, class, and gender (Puentes and Gougherty 2011), scientific methods (Lynch and Bogen 1997), and classical sociological theory (Connell 1997; Deegan 2003; Hamilton 2003; Harley 2008). Scholars have also criticized introductory textbooks for the classification of the discipline through an outdated understanding of competing theoretical perspectives, in particular, functionalism, conflict theory and symbolic interactionism (Manza et al. 2010). Differences between textbooks and advanced research, however, are not in themselves a problem, since they may be a consequence of the textbook genre itself and the intended audience. The aim of the textbook is not to present all the rich nuances of advanced scholarship, but to welcome the newcomer to a complex field and to provide a foundation that will allow the student to progress. Manza, Sauder, and Wright (2010: 271-2) note that textbooks "cannot meaningfully engage state-of-the-art debates at the core of the field," and that we should therefore expect differences between "textbook science" and advanced research. A central question in the scholarship on introductory textbooks, however, is whether the current differences between textbooks and advanced scholarship reflect practical concerns inherent to the textbook genre (for example, how to address the audience), or if other issues (for example, the publishing industry and text- 
book markets, the textbook peer-review process, the structure of the university as workplace, the rationalization of university teaching, or the hierarchical organization of sociology as a profession) have produced a problematic disconnection between textbook sociology and the broader discipline (Best and Schweingruber 2003; Kendall 1999; Manza et al. 2010).

In line with the scholarship on introductory textbooks, our paper also contrasts textbook sociology with advanced research, but our paper is not simply a critique of introductory textbooks for their presentation of Durkheim. Indeed, the use of Durkheim we found in introductory textbooks is more complex than we expected to find when we first started this research. While we did find a formulaic caricature of Durkheim as functionalist and conservative across the textbooks we examined, we also found his work plays a central role in the early pages of the textbooks. In the latter case, the textbook authors invoke Durkheim as a founder of the discipline and draw on his work for its capacity to make the social visible. In other words, his work appears at the very centre of what it means to think sociologically. The two presentations of Durkheim - as the initiator of the sociological project and as the founder of functionalism - are not inherently at odds, but they are nonetheless remarkably distinct and not easily reconciled. How are we to understand the incongruity between these two presentations of Durkheim? Answering this question requires examining the place of classical authors in introductory textbooks and the rhetorical work they do in representing the discipline to the neophyte.

We also want to take seriously the challenges authors face in producing strong textbooks (Roberts 2017: 38). While the audience for scholarly publications is typically other experts in one's own field, authors of textbooks must directly address issues that can be taken for granted or left aside in research sociology. In research publications, sociologists do not generally have to address questions of the coherence of the discipline, nor do they have to consider the relevance or public contribution of the discipline as such, at least beyond their specific research projects. Introductory textbooks, however, must directly confront all of these problems, and sociology is a notoriously fragmented and divided discipline, a problem often - and wronglyattributed to its youth (Alexander 1996). One challenge faced by authors of introductory books is how to present a coherent narrative about a deeply fragmented discipline. How can one book introduce the newcomer to the diversity of epistemological and theoretical positions in the discipline and the potentially unlimited areas of investigation? The classical authors, we argue, are central to this presentation of so- 
ciology to the newcomer, and they operate as expressive symbols for both the coherence and the divisions of the discipline.

In addition to the problem of how one tells a coherent story about the divisions in sociology, we also note another practical and troublesome issue about introductory teaching. Students enter our classrooms generally knowing little about sociology, since many did not encounter it in high school. Instructors cannot assume any background and must start at the beginning. But what exactly is the starting point in sociology? Where, in other words, should the textbook begin?

Our approach to these textbook problems and challenges is to treat introductory textbooks in Durkheimian terms, that is, as social facts and collective representations. Durkheim's work invites us to think about introductory textbooks precisely because he draws our attention to the practical uses of textbooks, to their symbolic and practical role in the classroom in representing the discipline and in welcoming the neophyte. As a social fact, the textbook is an instance of authority handed to new students that speaks on behalf of the sociological collective, and it expresses what the authors see as the core beliefs and practices of the discipline. As a collective representation, textbooks are filled with symbols and myths of the group. Sociology is itself a moral and professional community, in a Durkheimian sense, that must reproduce membership and identity, particularly at key "introductory" moments. Durkheim invites us to inspect the textbook as a site of myth and community making, and moreover, suggests that sociologistslike all groups-depend upon mythmaking. We argue that the reason for the two distinct Durkheims of the introductory text is perhaps less about the relation of the textbook to advanced research than the way the two Durkheims play distinct roles in the way textbooks represent the discipline to the neophyte. They provide a path to sociology's core myths and practices, and their symbolic role is oriented towards initiating the newcomer. Recognizing the symbolic role played by stylized caricatures of the classical figures like Durkheim is one step towards developing alternative narratives that are more in line with the research practices of the discipline.

This paper has three parts. First, we explain our method of data collection as we examine nine popular English-Canadian introductory textbooks for their representations of sociology and Durkheim. Second, we discuss our central finding that two contrasting Durkheims inhabit these textbooks, a tension that allows us to explore the implicit aims and challenges of initiating the new student in the introductory classroom. Third, we discuss the framing of Durkheim in textbooks around the origin myth of "founders" of the field of sociology. We 
conclude with a discussion of how textbooks might strengthen their representations of Durkheim on the basis of our findings.

\section{Method and Data Collection}

One way to locate the most frequently-used introductory textbooks in Canada would be to look at publishers' sales numbers. However, this would risk skewing our observations towards textbooks purchased by students who attend very large universities with very large introductory sociology classes. To mitigate this problem, we turned to university bookstore required reading lists. According to Universities Canada (2015) there are 62 English-instruction universities in Canada. Using their data on full-time enrolment we organized these universities into three groups: 1) the "big six" with enrolment over 29,000, 2) mid-sized universities with enrolment between 29,000 and 10,000, and 3 ) small universities with fewer than 10,000 students. We examined university bookstore textbook lists for the academic year of 2015-16, noting only the required books for students taking the first introductory level sociology course offered by the institution. We recorded 26 universities' required introductory booklists: 1) all sections from the "big six" for a total of 31 sections, 2) all sections from ten sampled from the 20 mid-sized universities for a total of 25 sections, 3) all sections from ten sampled from the 38 small universities for a total of 30 sections. Taken together, we examined 26 institutions and 86 sections of introductory sociology.

Across institutions, regardless of size, instructors appeared to make individual textbook choices, that is, few departments adopted a single text as a group. A total of 77 sections of 86 sampled $(88.5 \%)$ were taught with a textbook. The top nine adopted textbooks were each used in at least four sections and together they constituted $80.5 \%$ of the total sampled textbooks. Our examination of Durkheim content was drawn from these nine textbooks: Brym, New Society; Murray, Linden and Kendall, Sociology in Our Times; Ritzer and Guppy, Introduction to Sociology; Tepperman, Starting Points; Steckly and Letts, Elements of Sociology; Henslin, Glenday, Pupo, and Duffy, Sociology: A Down to Earth Approach; Brym and Lie, SOC+; Macionis and Gerber, Sociology; Tepperman, Albanese, and Curtis, Principles of Sociology. Our list provides us with a good selection of popular textbooks used in Canadian university classrooms, but we do not claim that our list includes all popular textbooks. Likewise, while the books we examined were all comprehensive survey texts, various alternative textbooks to 
the comprehensive introductory textbooks are available, for example, Beamish's The Promise of Sociology, as well as various slim "primer" books (e.g. Manza et al. 2010: 275).

We began our examination of the nine textbooks from the opening pages. We asked how the student/reader was addressed, and we looked for the authors' expressed intent in producing the text and how they invited the reader into it. We also used the table of contents and the index to locate Durkheim's name and then explore the thematic contexts in which he was used. Was Durkheim used in any way in these opening textual moves to justify the overall project and introduce the general field and tradition of sociology? And if Durkheim was given a privileged place (representing more than just another "perspective" in the fragmented field of sociological thought) what work did he do? Was he a "founder", and if so, was he treated as still relevant or a stepping-stone toward contemporary thought? How was he placed in terms of other classical thinkers? And after the first chapters, how and where did Durkheim appear in the texts, and toward what ends? Were there tensions between the approaches to Durkheim found across the overall text? As we discuss in the next two sections, we found two distinct versions of Durkheim's work, which we label below as Durkheim 1 and Durkheim 2.

\section{Durkheim 1: Making The SOCIAL Visible}

A useful way to introduce Durkheim 1 is to consider how authors introduced their own textbooks. All but one of the textbooks began by speaking directly to the student/reader in prefaces and introductory matter. These openings are framed as friendly "invitations", "letters" or testimonials, and they often address the reader directly as "you." They invite the reader to join what Durkheim would call a "moral community" of sociological practice. In the prefaces and introductory letters, authors introduced their books, and thus the discipline itself, by speaking about their personal motivations to take up the practice of sociology. Most stressed the transformative power of sociology as a way of looking at the world, how it disrupts common sense thinking and reveals previously overlooked dimensions of social life. Macionis and Gerber write that sociology "will change what you see" (2014: 4). Henslin et al. write that "As you read this text, you will find yourself looking at your own world in a different light" (2014: 3-5). Tepperman, Albanese, and Curtis (2009: 10) write that sociology "challenges existing ways of thinking" and that it will help "you to see the world 
through different lenses." Brym (2014: 3-5) recounts his own undergraduate experience of hearing other students try to define sociology in terms of its topics, but writes that he only later became "hooked" on the discipline once he encountered first hand its ability to disrupt everyday assumptions. While in their preface material authors turned to their own experiences of encountering the discipline to describe what is exciting about it, in the early chapters they turned to Durkheim to illustrate sociology's ability to reveal the social world in new ways. Durkheim 1, in other words, plays a central role in introducing the core of the discipline and its fundamental perspectives. He appears in the textbooks as a gadfly to common sense who does the central political and rhetorical work of making the social visible. Durkheim 1 thus expresses what is most fundamental in the discipline as a perspective on social life.

Typically, Suicide (1997b) (with The Rules of Sociological Method - hereafter, The Rules - as supporting evidence) was used to make the social appear.

What choice could be more personal than the decision to end your own life? But Émile Durkheim... showed that, even here, social forces are at work. (Macionis and Gerber 2014: 7)

... Durkheim treated suicide as a social fact.... [Y] ou might find this treatment strange.... (Streckley and Letts 2010: 16)

This examination [of suicide] will help to illustrate how the sociological perspective can clarify and sometimes overturn common-sense beliefs. (Brym and Lie 2012: 5)

Émile Durkheim refused to accept common sense explanations of suicide.... [H]e related suicide to the cohesiveness (or lack of it) in society.... (Murray et al. 2014: 6)

Moreover, Durkheim's texts were used to show that common sense is both the object of sociology's interest and its obstacle, as sociology is introduced primarily as the disruption of everyday assumptions toward institutional critique. Certainly, this was a common theme across Durkheim's work. The opening pages of The Rules and the closing pages of The Elementary Forms, bookend this point: 
... unless in sociology one ascribes to common sense an authority that it has lost for a long time in other sciences... the scholar must determinedly resolve not to be intimidated by the results to which his investigations may lead... (Durkheim 2013: 3)

And yet, common sense or opinion is sociology's very object:

To be sure, we can make opinion an object of study and create a science of it; that is what sociology principally consists in. (Durkheim 1995: 439)

Through the idea of the social fact, The Rules sets out to make the social a real imaginative possibility for Durkheim's audience (Cormack 1996). Likewise, in Suicide, Durkheim offers an object of inquiry (as he says he must) for the discipline - the social fact. His coup of turning suicide into a social fact is used to suggest that if suicide can be a social fact, then pretty much everything can be thus "treated" as he says. In making the social an imaginative possibility, Durkheim here initiates the group (i.e. sociologists, for whom the distinction between neophyte and professional is intentionally thin) by giving it - through the notion of the social - a sacred object, a symbol, and an identity to distinguish it from neighbouring academic disciplines, especially psychology and biology.

Common sense, ideology, and received opinion then are primary social facts to be considered by sociologists, as these actively discourage sociological thinking, justify the status quo, and obscure reality. This move takes on political traction quickly in the textbooks we considered. Three texts linked Canada's appalling rate of Indigenous suicide to Durkheim, and by framing it as a product of post-colonial lack of integration, they make Durkheim (and sociology) critically relevant to the Canadian reader. Murray, Linden, and Kendall discuss Suicide in the context of explaining functionalism, and end with a powerful quotation from the 1995 Royal Commission that connects colonial administration and suicide to "collective anguish" (2014: 18). Durkheim's pronouncement that social facts can only be explained by other social facts invites the student to think of contemporary Canada as an inherited colonial (and hence hegemonically invisible to the most privileged) legacy of oppression.

Not surprisingly, then, Durkheim shares textual privilege with C. Wright Mills and his "sociological imagination." For Mills, too, reality is obscured by the everyday, as ordinary people are unable to produce "lucid summations" of their experiences (1959: 5). Durkheim offers his readers in The Rules examples of their own ordinary and contemporary life when asking them to begin to think sociologically, for ex- 
ample, being a brother, an entrepreneur, speaking with others in colloquial language, and using currency (2013: 20). Because we "cannot do otherwise" than make use of these conventions, this ordinary world is the opportunity to begin to make the familiar strange by rendering the social visible. What are the duties of being, for example, a sibling, as students both experience it and reflect on the moral category?

To sum up, we can consider Durkheim's "first and most basic rule" of sociology, his famous imperative to "consider social facts as things" (2013: 7, 29). Sociologists have often read this rule with the emphasis at the end of the sentence, on the "thingness" of the social, as external and constraining. However, just as Durkheim's first rule of method claims an ontological status for social reality analogous in certain ways to physical reality, the directive, because it is written in the grammatical mood of the imperative, also calls on the reader to "consider" or "treat" it as such. The sentence calls on the impersonal "you"- the general reader of The Rules - to develop a new sociological sensibility. The imperative stresses, in other words, that to treat social facts as things "is to observe towards them a certain attitude of mind" (2013: 7). Moreover, for Durkheim, sociology's aim is to ensure that this new attitude or quality of mind, an attitude that is able to reveal the social dimension of everyday life, attains the widest possible appeal (1961: 251). Likewise, it is precisely one aim of the introductory course to invite interested students to develop this "attitude of mind," and a central goal of the textbook is to welcome and initiate the neophyte, and to show what is exciting and valuable about the sociological way of looking at problems. Most crucially, the sociological perspective is not just for experts or advanced researchers, but can be put to use by students within and beyond the classroom. Durkheim 1 thus speaks directly to the student and extends an invitation to take up the sociological perspective.

\section{Durkheim 2: The Functionalist Durkheim}

In contrast to the imaginative use of the sociological perspective in Durkheim 1, we also found a second interpretation of Durkheim's work that caricatures him as "the founding figure of the functionalist theoretical tradition" (Murray et al. 2014: 12). As noted in the previous section, if we consider Durkheim's famous imperative to "treat social facts as things," then the emphasis of Durkheim 1 falls on the active stance of treating social facts, and thus on people's capacity to adopt a new sociological outlook. By contrast, the emphasis of Durk- 
heim 2 falls at the end of the sentence, on the "thingness" of the social rather than the stance the actor can take to it, and thus on the constraining power of society over the individual. As Fields puts it, under this Parsonian-inspired reading of Durkheim (who, she says of the former, liked to take the verbs out of Durkheim's thought) the action of social life is muted (2005: 172). Murray, Linden, and Kendall write that "Durkheim stressed that people are the product of their social environment" and they describe a "neglect of agency" in Durkheim's work brought on by an "overemphasis on structure and the determining power of "society"' (2014: 12). In this presentation of Durkheim, textbook authors stressed the weight of society's constraining power as it bears down on individual desires.

The most important difference between the two Durkheims is that Durkheim 1 is understood broadly, as representing the core of the discipline, for example, "as one of the deepest roots of the sociological imagination," as Murray, Linden, and Kendell (2014: 12) describe him through a quotation from Durkheim scholar Edward Tiryakian. Durkheim 2 , by contrast, is decidedly narrower, and he stands as the key representative and founder of modern structural functionalism. All the textbooks describe Durkheim as a functionalist, and Durkheim 2 is an extension of the textbook tradition of sorting sociological thought into contending "perspectives," each of which is said to provide a different lens on the social world. Being distinct, the two Durkheims appear in different parts of the books. Durkheim 1 makes an appearance in the early pages when authors introduce the sociological perspective and discuss its value. Durkheim 2, by contrast, appears throughout the textbooks as the key figure the authors invoke to introduce the functionalist perspective on topics such as education, crime and deviance, family, and religion.

Once Durkheim is identified as a functionalist, explanations of his work conform to that frame, including to functionalism's now notorious conservative implications, in the sense that it often justifies what it analyzes. As Brym and Lie (2015: 12) write, by stressing the power of society to restrain individuals and their desires, Durkheim's functionalism provides "a conservative response to widespread social unrest" in modern Europe, and they contrast Durkheim's work with those who provide more radical "conflict perspectives" on modern social unrest. Likewise, Ritzer and Guppy (2014: 45) write that "Durkheim had a largely negative view of people as being slaves to their passions, such as lust, gluttony, and other deadly sins. Left to their own devices... people would seek to satisfy those passions.... They need social facts that are capable of limiting and controlling their passions." In these in- 
terpretations, we see the classically conservative vision of society that emphasizes the constraining power of tradition and society to restrain an unruly and selfish human nature. While the relation of the individual to the collective in Durkheim is complex (and highly debated), Durkheim generally rejected this style of theorizing that begins from human nature, whether in its Rouseauian or Hobbesian versions, as well as the conservative worldview based on the idea of a selfish nature in need of control (Durkheim 1960; 1973). Certainly, Durkheim's work has been influential over twentieth-century functionalism, and over conservative traditions within sociology. The point we stress here is only that textbooks reproduce a selective account of Durkheim's work that would make him fit the functionalist box. They also downplay those aspects of his thinking that contemporary Durkheim scholars now emphasize, such as his socialism, the value of the sacred and profane for understanding issues of justice, culture and meaning, and the relation of those meanings to everyday rituals and practices (Durkheim 1973; Datta and Milbrandt 2014; Horgan 2014; Mallory and Carlson 2014). The selective reading of Durkheim as a conservative defender of order arises from overstating the contrast between Durkheim qua functionalist with other perspectives that emphasize subjective meanings (symbolic interactionism) or power, inequality, and injustice (conflict perspectives).

While the two Durkheims are distinct, they are not inherently at odds. Indeed, some textbook authors and teachers put the functionalist Durkheim to use in the classroom to challenge common sense and unsociological visions of society. Colleagues have told us, for example, that they use the functionalist Durkheim to get students to think holistically about society and, therefore, to see it as more than a collection of self-interested individuals. Likewise, the very presentation of contending paradigms can help to show there are multiple ways of viewing any social issue, and thus to reinforce for students that one cannot take any particular view for granted. Likewise, Durkheim's own examples that are now treated as classically functionalist, such as his discussion of the functions of crime, are deliberately provocative and designed to challenge common-sense thinking. Significantly, his choice of crime in The Rules is not found within a general consideration of crime. It is an example brought up to make a point. And, as is the case with the Suicide text, the aim of the example is to shock common sense by stressing that crime paradoxically shows "all the symptoms of normality" (2013: 61). His rhetoric becomes evident when he makes the flourish that an (impossible) community of saints would have to invent crime to have something to morally deride (and 
integrate itself). Durkheim's rhetoric is indeed functionalist in this passage, but it is embedded in his discussion of how to take up and "treat" social facts. His playfulness is important to his method, making fun of his morally outraged reader and turning saints into sinners.

In spite of these potential similarities between the two Durkheims, the differences between the two versions of his work are more striking. Durkheim 1 appears as a founding figure that expresses the core of the sociological imagination, and textbooks emphasize the critical edge of this Durkheim, namely, the way this Durkheim begins with everyday common sense in order to disrupt it. The relation of Durkheim 2 to a critique of common sense thinking is, however, much less clear. As the bearer of the functionalist tradition, Durkheim 2 even comes to stand in for unreflective common sense itself, in part because the functionalist Durkheim is presented as a conservative defender of order over disruption. As the symbolic father of functionalism, he comes to stand in for functionalism's faults, in particular, that searching for functions has a way of justifying the status quo. At the same time, Durkheim 2 is not particularly well developed in the textbooks. Typically, this reading of Durkheim is given only a brief discussion as way to introduce the section on functionalist approaches to the various topics the textbooks address. The question we should ask is why should such a cursory reference to Durkheim be necessary at all when the textbooks turn to the functionalist perspective? Why do these two distinct readings of Durkheim persist at all? We turn to these questions in the next section.

\section{Sociological Mythmaking}

In The Rules, Durkheim lists "Myths, popular legends, [and] religious conceptions of every kind" (2013: 11) as types of collective representations. For Durkheim, myth is central to all collectives, and myths give rich narrative content by which a collective can bring itself into existence and maintain itself over time (1995: 291). The importance of myth also applies to sociology and textbooks because, as social facts and collective representations, they are key sites for sociological mythmaking. Each of the textbooks we examined begins with a chapter that addresses the history of the discipline, the social contexts for its emergence, and the "founders" who contributed to its development. While the textbook authors presented their account of sociology's intellectual history as objective, as a setting out of the facts of its historical origins and development, these histories also carry an important "mythic" quality that is central to the presentation of the discipline. As 
Kurasawa writes, "Like all scholarly disciplines, Western sociology is grounded in a foundational myth that shapes its self-understanding and fuels its developmental narratives" (2013: 188). The introductory textbook is one place where sociology's foundational myths are particularly evident.

Connell (1997) has identified and critiqued one important form of sociology's foundational myth - that the discipline emerged through the efforts of a small group of brilliant authors contemplating Western modernity and its nineteenth-century upheavals. This foundational myth, Connell notes, is widely accepted by sociologists, and we found it consistently present in each of the texts we examined. All authors stress the impact of the industrial revolution in sociology's emergence, as well as various other European upheavals and revolutions, such as urbanization, and the scientific and democratic revolutions. Only one text mentions imperialism and colonialism (Henslin et al. 2014: 7-8) in this context. Of the founding authors, Marx, Weber, and Durkheim receive by far the most attention, alongside a set of second-tier early theorists that varied between textbooks, such as Comte, Mead, or Simmel. As well, several of the textbooks expanded the classical tradition beyond white male theorists by including sociologists such as Du Bois and Martineau. In spite of these revisions, the story of the origins of sociology is nonetheless presented through the efforts of a rather small group of European authors that the textbooks describe as "founding figures" (Tepperman 2011: 7), "trailblazers" (Steckley and Letts 2010: 3), and "giants" (Ritzer and Guppy, 2014: 38).

The problem is not myth as such, particularly since, as Kurasawa notes above, all disciplines necessarily have some kind of foundational narrative. But, as Barthes (1973) put it, myths have a way of turning history into nature, of making what is complex and contingent appear as straightforward, obvious, and taken for granted. One issue with sociology's foundational narrative according to Connell (1997) and Kurasawa (2013) is that sociology's deep connections to colonialism simply vanish. Likewise, Marx, Weber, and Durkheim have not always been timeless classics at the origin of the discipline, and have only been understood so since the 1960s (Connell 1997). In addition, a narrow focus on the late nineteenth-century origins of sociology overlooks that the concept of the "social" emerges much earlier in the eighteenth and early nineteenth centuries (Curtis 2016; Singer 2013). In other words, more is going on in these introductory chapters than the presentation of the best historical work on the development of the discipline. In fact, these chapters are more an exercise in myth mak- 
ing, and the classical authors play a central role in the making of these myths.

But why would sociologists choose to present the discipline in terms of classical founding figures? After all, as Levine argues (2015), one way for a social science discipline to adopt a scientific pose is for its practitioners to cut ties to its classical authors and instead devote their efforts to the empirical study of the present. Sociology, however, has not yet done so (Levine 2015: 306) and, in fact, sociology is unique in the social sciences in this regard (Poggi 1996; Connell 1997: 1515). What is it about sociology that suggests a central place for classical authors? And why would sociologists frame their discipline in terms of myths about founders?

According to Levine, from one perspective the classical authors can be seen as "expressive symbols within the community of sociologists, performing ritual functions to represent collective solidarity within a dispersed and fragmented discipline" (2015: 312). In this sense, "the classic author becomes a collective representation for the profession" (2015: 312). The classical authors operate, in other words, as stylized totemic figures that symbolize the collective and express both its unity and its divisions. Durkheim, as noted above, appears in both senses in textbooks, as representing both the core of the discipline and one corner of it.

In the first sense, as "founder" of the discipline, Durkheim provides a particularly clear account of the idea of the social - the discipline's most central concept - as well as the methodological and theoretical resources to render it visible. As Baehr argues, Durkheim is a "deliberative" and "continuous founder" of the discipline and the institution of sociology, but as a discourse, sociology debates and reinvents its founders while it also relies on them to provide a certain "sacred status" to the practice (2002: 44). Even today, the status of the social as an empirical object is by no means established, and beyond the discipline it can still be invoked or denied with all the political stakes that invoking or denial presupposes (Ramos 2017). Thus, in the first instance, Durkheim is presented as a founder of sociology's most central concept, the social. The idea of the social is still today, as it was for Durkheim, the discipline's most powerful totem (Cormack 2002). It is belief in the value of making the social visible that lends coherence to sociology as a profession, and the textbook authors turn to Durkheim to represent this coherence.

On the other hand, Durkheim appears in introductory textbooks not just as a founder of sociological discourse as such, but also of only one corner of it. Retrospectively, he was presented as the "founder" of 
the functionalist perspective. All of the nine textbooks we consulted present sociology in terms of competing paradigms. And rather than as symbols of solidarity for a whole professional community, the classical authors are also invoked as more limited symbols, as representatives of one competing paradigm. As Brym writes, "Durkheim, Marx, and Weber initiated three of the major theoretical traditions of sociology: functionalism, conflict theory, and symbolic interactionism" (2014: 14). Our discipline thus appears the product of ancestors, founding "fathers," each of whom directly gives rise to a separate theoretical lineage. Such a story is certainly more mythical than accurate, more about classifying and representing, than an actual intellectual or institutional history of sociology.

The textbook authors also invoked the classical authors as symbols in a different sense, as representing the moral and ethical aspiration of the discipline. A frequent topic in the opening chapters was the possible tensions and points of congruence between a value-free science and the ethical motivations that inspire one to take up sociological work, such as a desire to "alleviate human suffering" (Henslin et al. 2014: 11) or "bring about change toward social justice" (Macionis and Gerber: 2014: 13). Brym, for example, writes that the classical authors "wanted to chart a better course for their societies" and that their ideas are "not just diagnostic tools from which we can still learn much, but also, like many sociological ideas, prescriptions for combating social ills" (2014: 12). Here we might see again sociology's foundational myth - that the discipline emerged as a response to the upheavals and injustices of the modern world, as an attempt by the founders to understand these problems but also alleviate them. The textbook authors, in other words, draw on the classical authors to present sociology as a moral community of belief and action. Every profession, as Durkheim (1961; 1996; 1997a: xxxi-lvii) argued, is a type of moral community, and this is certainly true of sociology, which as a discipline is reflexive about its ethical and moral commitments to the promotion of justice and the public good. Indeed, the discipline is defined morally by the injustices it reveals and works against (Alexander 2011). It is not surprising that such representations of the discipline appear at introductory moments, when sociologists must communicate to the newcomer what precisely sociology is, what holds it together, and why it holds value for students' lives as citizens and for our societies. 


\section{Conclusion}

Let us return to the first moment of this paper. We wondered about students' experiences of sociology and of Durkheim in their introductory sociology classes, especially as they first encounter him in their textbooks. As Durkheim scholars who find him infinitely exciting, we wondered if something was going wrong in the early days of initiation into the sociological world. At some level, this is a practical problem, as students arrive in upper-level theory courses with a less than enthusiastic attitude toward picking up Durkheim's texts. Since Durkheim studied how communities bring themselves into existence through collective representations that both reflect and reinforce the group (including the practice of myth), and since he offered sociology its own sacred rites and categorical language, we asked how Durkheim would read these introductory textbooks. Thus, we asked how textbooks can be treated as social facts, collective representations, and sites of myth, and what this type of analysis might suggest in terms of the ongoing issue of how to revisit our textbook conventions.

In the textbooks we examined we found that Durkheim played a privileged role in this initiatory gesture in that he invited students to question common sense, take up the social world, and find wonder in this engagement. On the other hand, when textbooks presented students with the contending paradigms or perspectives version of the founding thinkers, Durkheim was framed as a structural-functionalist, and even served in places as a straw man to illustrate the failures of functionalism. While in the former version, textbooks use Durkheim's work to illustrate the power of sociology to disrupt common sense, in the latter version, his work comes to stand in for unreflective common sense, even though Durkheim explicitly made common sense sociology's ongoing object of interest and intervention.

We found that students encounter a narrative of the discipline aimed to initiate them into it and that this narrative is rooted in a myth of "founders." This myth allows a clean moment of origin that springs, as the story goes, from the founders' reflections on the social upheaval of their own time and place. Hence, the founders represent the "discovery" of the social, a moment to be ritualistically repeated by neophytes through time and space. While the content of this practice will change, as neophytes face the versions of common sense present in their own everyday world, the generalized gesture of treating social facts as things - with all the challenges this implies - does not.

One of the most significant findings from our examination of introductory textbooks was that authors express a version of sociology as 
a moral community and intervention in the everyday, one that treats students as sociological thinkers able to reflect on their own everyday world. We found this account of the discipline in their most enthusiastic passages, ones that were often autobiographical. These passages were strikingly in line with Durkheim's formulation of the sociological project, especially as set out in The Rules. Understood as social facts and collective representations, introductory textbooks cannot and should not simply represent the content of the field of sociology, as in an encyclopaedic overview, as Brym put it (2014: xxi). Instead, as objects for use in an introductory classroom, they aim to welcome the neophyte into a moral community of sociological practice, and they do so in part by reiterating the origin myths on which that community is based.

For decades scholars have debated the merits and demerits of introductory textbooks, with most scholars - including textbook authors themselves - expressing concerns about problems with these textbooks, particularly when they diverge too far from the research practices of the discipline in ways that lack a pedagogical justification. To understand textbooks, their challenges and their problems, scholars have considered the textbook markets and publishing industry, the peer review process, the rationalization of university teaching and learning, the hierarchical structure of the discipline and university faculty, and the working conditions of university teachers (Westhues 1991; Kendall 1999; Best and Schweingruber 2003; Manza et al. 2010; Wright 1995). Our understanding of sociology textbooks would be incomplete, however, if we do not also locate their use in the classroom, as objects designed to welcome neophytes and initiate them into the core beliefs and practices of the discipline. And perhaps this gives us a perspective on the classical authors as they appear in introductory books, and why they operate as symbols - or better - as totems for sociology's competing approaches (Alexander 1996; Levine 2015: 312). The reason for the persistence of the two Durkheims is that each plays a different role in the presentation of the discipline to the newcomer: one represents the core of the sociological perspective and the way the discipline begins with common sense in order to disrupt it, while a second stands as a symbol for only one small part of the discipline. Thus, the classical figures and their theoretical lineages are one solution to the difficult task of representing both the coherence and divisions of the discipline.

We wonder, however, if it is time to let Durkheim (and others) out of their corners as contending perspectives, as (at least in the case of Durkheim) this textual and rhetorical placement as the classical founder of functionalism undermines so much of the promise he makes as an 
initiator of the discipline in general. But, if we take seriously the idea that collectives bring themselves into existence by way of classification, we have to acknowledge that introductory textbooks are practices of sorting and classifying. Could sociology textbooks make better use of classical and contemporary thinkers toward these ends by resisting the desire to classify them in strict and mutually exclusive labels? The promises (and tensions) we found in Canadian sociology textbooks indicate that the answer is yes. In this sense, we agree with those scholars who argue that the theoretical division of textbook sociology into conflict theory, symbolic interactionism, and functionalism no longer reflects the discipline's core research practices. Our analysis of the two Durkheims is one step towards appreciating the work this theoretical triptych does in textbook sociology, and therefore, we hope, one contribution towards developing better alternatives.

Finally, our aim is not to insist on one true interpretation of Durkheim that all introductory textbooks must reproduce, since, like any specialization, contemporary Durkheimian scholarship is alive with debate. We do suggest, however, that our textbooks could be more reflective of contemporary scholarship if they retained the promise of Durkheim 1 and de-emphasized the functionalist Durkheim. One strategy for revising the presentation of Durkheim in introductory textbooks would be to make room for the new Durkheim scholarship that emphasizes The Elementary Forms (Alexander and Smith 2005; Datta and Milbrandt 2014). This new scholarship turns to Durkheim's work to theorize pressing current problems of social solidarity through culture and symbols, social interaction and everyday practices, questions of justice and injustice, and the sacred and profane. In other words, the new Durkheimian scholarship does not neatly fit the functionalist box. Rather than making it fit, our textbooks could present the classical authors less as symbols of contending perspective and more as rich and complex resources that we can still use to understand pressing contemporary problems. That is precisely what the authors of introductory textbooks do when, for example, they turn to Durkheim to understand the issue of indigenous suicide in Canada. It is not that Durkheim addressed this topic himself, but that we can draw on his concepts to illuminate the legacy of colonial violence in Canadian society today. 


\section{REFERENCES}

Alexander, Jeffrey C. 1996. The centrality of the classics. In Social Theory and Sociology: The Classics and Beyond, edited by S. Turner, 21-38. Cambridge, MA: Blackwell.

Alexander, Jeffrey C. 2011. Fact-signs and cultural sociology: How meaningmaking liberates the social imagination. Thesis Eleven 104 (1): 87-93.

Alexander, Jeffrey C. and Phillip Smith. 2005. The Cambridge Companion to Durkheim. Cambridge: Cambridge University Press.

Baker, Paul. 1988. Sociology textbooks: Managing clones or writing works of distinction. Teaching Sociology 16 (4): 381-83.

Best, Joel and David Schweingruber. 2003. First words: Do sociologists actually use the terms in introductory textbooks' glossaries? The American Sociologist 34 (3): 97-106.

Baehr, Peter. 2002. Founders, Classics, Canons. London: Transaction.

Barthes, Roland. 1973. Mythologies. London: Paladin.

Beamish, Rob. 2010. The Promise of Sociology: The Classical Tradition and Contemporary Sociological Thinking. Toronto: University of Toronto Press.

Brym, Robert. 2014. New Society, 7th edition, Toronto: Nelson.

Brym, Robert and John Lie. 2012. SOC+ , 2nd edition, Toronto: Nelson.

Carroll, Michael P. 2017. "World Religions" in introductory sociology textbooks: In search of the sociology. Teaching Sociology 45 (1): 28-37.

Collins, Randall. 2004. Interaction Ritual Chains. Princeton, NJ: Princeton University Press.

Connell, R.W. 1997. Why is classical theory classical? American Journal of Sociology 102 (6): 1511-57.

Cormack, Patricia. 1996. The paradox of Durkheim's manifesto: Reconsidering The Rules of Sociological Method. Theory \& Society 25 (1): 85-104.

- 2002. Sociology and Mass Culture: Durkheim, Mills, and Baudrillard. Toronto: University of Toronto Press.

Curtis, Bruce. 2016. The missing memory of Canadian sociology: Reflexive government and "the Social Science." Canadian Review of Sociology 53 (2): 203-25.

Datta, Ronjon Paul and Tara H. Milbrandt. 2014. The Elementary Forms of Religious Life: Discursive monument, symbolic Feast. Canadian Journal of Sociology 39 (4): 473-522.

Deegan, Mary Jo. 2003. Textbooks, the history of sociology, and the sociological stock of knowledge. Sociological Theory 21 (3): 298-305. 
Durkheim, Émile. 1960 [1892/1918]. Montesquieu and Rousseau: Forerunners of Sociology, translated by R. Manheim. Ann Arbor: University of Michigan Press.

1961 [1925]. Moral Education, translated by E.K. Wilson and H. Schnurer. New York: Free Press.

- 1973 [1898]. Individualism and the intellectuals. In Emile Durkheim: On morality and society, edited by R. Bellah, 43-57. Chicago: University of Chicago Press.

1995 [1912]. The Elementary Forms of Religious Life, translated by K. Fields. New York: Free Press.

_. 1996 [1950]. Professional Ethics and Civic Morals. New York: Routledge.

- 1997a [1893]. The Division of Labor in Society, translated by W. D. Halls. New York: Free Press.

_. 1997b [1897]. Suicide: A Study in Sociology. New York: Free Press.

- 2013 [1895]. The Rules of Sociological Method and Selected Texts on Sociology and its Method, translated by W. D. Halls. New York: The Free Press.

Fields, Karen E. 2005. What difference does translation make? Les Formes élémentaires de la vie religieuse in French and English. In The Cambridge Companion to Durkheim, edited by J.C. Alexander and P. Smith, 160180. Cambridge: Cambridge University Press.

Gane, Mike. 1992. The Radical Sociology of Durkheim and Mauss. New York: Routledge.

Garfinkel, Harold. 2002. Ethnomethodology's Program: Working Out Durkheim's Aphorism. Lanham: Rowman \& Littlefield.

Hamilton, Richard. 2003. American sociology rewrites its history. Sociological Theory 21 (3): 281-97.

Harley, Kirsten. 2008. Theory use in introductory sociology textbooks. Current Sociology 56 (2): 289-306.

Henslin, James, Dan Glenday, Norene Pupo, Ann Duffy. 2014. Sociology: A Down to Earth Approach, 6th edition. Toronto: Pearson.

Horgan, Mervyn. 2014. Durkheim, development and the devil: A cultural sociology of community conflict. Canadian Journal of Sociology 39 (4): 741-64.

Keith, Bruce, and Morten G. Ender. 2004. Core, what core? Looking beyond the introductory textbook for answers. Teaching Sociology 32 (1): 39-40.

Kendall, Diana. 1999. Doing a good deed or confounding a problem? Peer review and sociology textbook authors. Teaching Sociology 27 (1): 17-30. 
Kurasawa, Fuyuki. 2013. The Durkheimian school and colonialism: Exploring the constitutive paradox. In Sociology and Empire: The Imperial Entanglements of a Discipline, edited by George Steinmetz, 188-209. Durham: Duke University Press.

Levine, Donald N. 2015. The variable status of the classics in differing narratives of the sociological tradition. Journal of Classical Sociology 15 (4): $305-20$.

Lewis, Tammy, and Craig Humphrey. 2005. Sociology and the environment: An analysis of coverage in introductory sociology textbooks. Teaching Sociology 33(2): 154-69.

Lynch, Michael, and David Bogen. 1997. Sociology's asociological 'core': An examination of textbook sociology in light of the sociology of scientific knowledge. American Sociological Review 62(3): 481-93.

Macionis, John and L.M. Gerber. 2014. Sociology, 8th ed. Toronto: Pearson.

Mallory, Peter, and Jesse Carlson. 2014. Rethinking personal and political friendship with Durkheim. Distinktion: Journal of Social Theory 15(3): $327-42$.

Manza, Jeff, Michael Sauder, and Nathan Wright. 2010. Producing textbook sociology. Archives Européennes de Sociologie 51 (2): 271-304.

Mills, C. Wright.1959. The Sociological Imagination. New York: Oxford University Press.

Murray, Jane, Rick Linden, Dianne Kendall. 2014. Society in Our Times, 6th edition. Toronto: Nelson.

Pearce, Frank. 2001. The Radical Durkheim, 2nd edition. Toronto: Canadian Scholars' Press.

Platt, Jennifer. 2008. Introduction. Current Sociology 56 (2): 147-64.

Poggi, Gianfranco. 1996. Lego quia inutile: An alternative justification for the classics. In Social Theory and Sociology: The Classics and Beyond, edited by S. Turner, 39- 47. Cambridge, MA: Blackwell.

Puentes, Jennifer, and Matthew Gougherty. 2011. Intersections of gender, race, and class in introductory textbooks. Teaching Sociology 41 (2): 159-171

Ramos, Howard. 2017. Sociology as dangerous or farce. Canadian Review of Sociology 54 (3): 369-71.

Ramp, William. 2008. Introduction: Durkheim redux. Journal of Classical Sociology 8 (2): 147-57.

Rawls, Anne W. 2004. Epistemology and Practice: Durkheim's the Elementary Forms of Religious Life. Cambridge: Cambridge University Press.

Ritzer, R. and N. Guppy. 2014. Introduction to Sociology: A Canadian Version. Los Angeles: Sage. 
Roberts, Keith. 2017. Description versus sociology in introductory textbooks. Teaching Sociology 45 (1): 38-40.

Schweingruber, David. 2005. Looking for the core in the wrong place. Teaching Sociology 33 (1): 81-89

Schweingruber, David and Ronald Wohlstein. 2005. The madding crowd goes to school: Myths about crowds in introductory sociology textbooks. Teaching Sociology 33 (2): 136-53.

Singer, Brian. 2013. Montesquieu and the Discovery of the Social. New York: Palgrave Macmillan.

Smith, Philip, and Jeffrey Alexander. 2005. Introduction: The new Durkheim. In The Cambridge Companion to Durkheim, edited by P. Smith and J. Alexander, 1-37. New York: Cambridge.

Steckley, John, and Guy Kirby Letts. 2010. Elements of Sociology: A Critical Introduction, 2nd edition. Don Mills, ON: Oxford University Press.

Tepperman, Lorne. 2015. Starting Points: A Sociological Journey, 2nd edition. Don Mills, ON: Oxford University Press.

Tepperman, Lorne, Patrizia Albanese, James Curtis (eds.) 2014. Principles of Sociology: Canadian Perspectives, 3rd edition. Don Mills, ON: Oxford University Press.

Universities Canada. 2015. 2015 Full-time and Part-time Fall Enrolment by Canadian Universities, http: //www.univcan.ca/universities/facts-andstats/enrolment-by-university, (accessed Nov 30, 2015)

Westhues, Kenneth. 1991. Transcending the textbook world. Teaching Sociology 19(1): 87-92.

Wright, Richard A. 1995. Was there a 'golden past' for the introductory sociology textbook? A citation analysis of leading journals. The American Sociologist. 26(4): 41-8.

\section{ACKnowledgements}

We thank Laura Eramian, Lynda Harling Stalker, the members of the Canadian Network for Critical Sociology, and the anonymous peer reviewers for their valuable comments and criticisms. We presented a version of this paper at the annual conference of the Canadian Sociological Association, and we thank William Ramp, Tara Milbrandt and other members of the Canadian Network of Durkheimian Studies for their support and critical feedback. Thanks also to Yvon Grenier for translating the abstract. 
Peter Mallory is an Associate Professor in the Department of Sociology at St. Francis Xavier University. His research focuses on social theory and personal life, and he has published articles on friendship in the works of Alexis de Tocqueville, Adam Smith, and Émile Durkheim. He is currently working on a collaborative research project on how friendships end.

E-Mail: pmallory@stfx.ca

Patricia Cormack is a Professor of Sociology at St. Francis Xavier University. She studies classical theory, state formation, media, celebrity, and nationalism. With James F. Cosgrave, she wrote Desiring Canada: CBC Contests, Hockey Violence, and other Stately Pleasures (University of Toronto Press). She has recently written on Justin Trudeau and celebrity and well as the Ghomeshi scandal at the $\mathrm{CBC}$.

E-Mail: pcormack@stfx.ca 